Int. J. Odontostomat., 8(2):221-224, 2014.

\title{
Tooth Loss Related to Root Perforation: Legal Approach in Endodontic Practice
}

\author{
Perdida Dentaria Relacionada con una Perforación Radicular: \\ Una Visión Legal en la Práctica Endodóntica
}

\begin{abstract}
Isamara Geandra Cavalcanti Caputo*; Ana Cláudia Rossi*; Alexandre Rodrigues Freire ${ }^{* *}$; Débora Campanella Bastos $^{* *}$; Manuel Gustavo Chavez Sevillano*; Eduardo Daruge Júnior ${ }^{* *}$ \& Felippe Bevilacqua Prado ${ }^{* *}$
\end{abstract}

CAPUTO, I. G. C.; ROSSI, A. C.; FREIRE, A. R.; BASTOS, D. C.; SEVILLANO, M. G. C.; JÚNIOR, E. D. \& PRADO, F. B. Tooth loss related to root perforation: legal approach in endodontic practice. Int. J. Odontostomat., 8(2):221-224, 2014.

ABSTRACT: Most of the techniques used in endodontic treatment are limited to the internal space to the tooth, avoiding reaching the periapical region. However, some accidents can happen, such as fracture of endodontic instruments, perforation, leakage of material, tooth fracture among others, depending on the complexityof each case. The aim of this study was to report a case involving a tooth loss caused by root perforation. In this case, the patient filed a lawsuit against the former professional who had performed endodontic treatment requiring compensation for moral and material damages. In conclusion, the practice endodontic the clarification of the risks is crucial, considering the particularities of each case. Thus, it is suggested that the verbal and written information should be offered to patients.

KEY WORDS: radicular perforation, accident, endodontic treatment, legal odontology.

\section{INTRODUCTION}

Despite technological advances in dental instrumentation and in the development of dental materials, endodontic incidents are frequently found in dental practice. Unfortunately, accidental root perforations during access preparation, canal instrumentation or preparation of post space are not uncommon. Instrument fractures during filing or reaming, as well as root fractures during condensation are still frequent (Motamedi, 2006). In addition, perforations can be caused by artificial and involuntary injuries as root resorption and caries promoting communication between the pulp cavity and the periodontal ligament.

Considering that the anatomy of root canal is extremely variable and dental roots can show abnormal curvatures, these accidents are, mostly, difficult to avoid specially during the root access, cleaning and preparation. However, these incidents can delay endodontic therapy and increase risk of treatment failure, especially in teeth with necrotic pulps and periradicular lesions (Motamedi). According to Arens \& Torabinejad (1996) the lack of knowledge in dental anatomy, atypical tooth position in the arch, presence of prosthetic crowns, calcified pulp chamber and inappropriate use of endodontic instruments are the most common causes of iatrogenic perforations. Since the root perforation and its clinical complications can strongly affect the patient with the possibility of tooth loss and the dentist in ethical and legal implications, the aim of this study is to report a case involving a tooth loss caused by root perforation, which resulted in a judgment against the professional in a civil procedure, highlighting the importance of explaining the risks of the endodontic treatment to the patient.

\section{CASE REPORT}

In July 2007, a 30-year-old female patient was referred to an expert of the Department of Social Odontology, Forensic Odontology Area, State University of Campinas - UNICAMP, Piracicaba, SP, Brazil, showing the absence of tooth 21 in order to verify

\footnotetext{
* Faculty of Medicine of Ribeirao Preto, Sao Paulo University - USP, Ribeirão Preto-SP, Brazil.

"Piracicaba Dental School, State University of Campinas - UNICAMP, Piracicaba-SP, Brazil.
} 
the legitimacy of the procedures performed in the endodontic treatment of the same tooth and to verify whether the complications presented could be caused by this treatment.

In September 2005, the patient visited a dentist (in Piracicaba-SP) complaining of pain in the region of the maxillary incisor. According to her report, the patient was initially conducted to an Xray examination, which revealed endodontic involvement of the upper left incisor. The patient underwent a painful and long endodontic treatment, which was completely finished only in December of the same year (Fig. 1).

We analyzed this X-ray, which showed a radiopaque area within the root canal from the middle third the apical of the pulp chamber, suggesting the presence of a pulp calcification The X-rays sent to the expert showed a poor image quality, with stains and low contrast, which hampered visualization of the structures.

Around 8 months after the treatment was performed by this professional, the patient sought to report some symptoms to the dentist (pain and darkening of the upper left incisor). The provider informed that her upper left incisor was weak and advised her to perform a prosthetic crown to prevent its fracture. The proposed treatment was not performed at that time. When the patient returned to the professional's office, he did paste the dental fragment previously fractured and a root canal retreatment was performed. As the first time, she reported that the treatment was painful. Since the pain was not decreasing, the patient decided to ask for a second opinion. She visited another professional who, after examination, diagnosed tooth mobility. The X-ray performed at that time showed a fracture in the cervical portion of the crown also involving the cervical portion of the root. Thus, the tooth was indicated for extraction (Fig. 2). In intra-oral aspect (Fig. 2A) and a post-extraction X-Ray (Fig. 2B), we observed inherent bony loss.
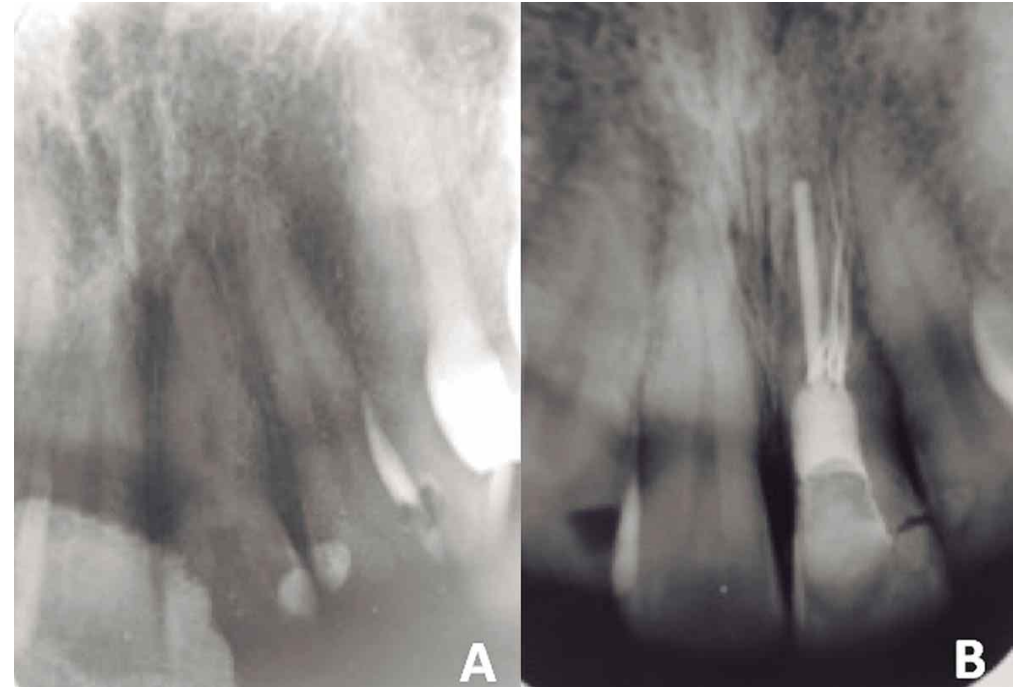

Fig. 1. A. Initial radiograph. B. Final radiograph of endodontic treatment. The radiographs were provided by the professional.

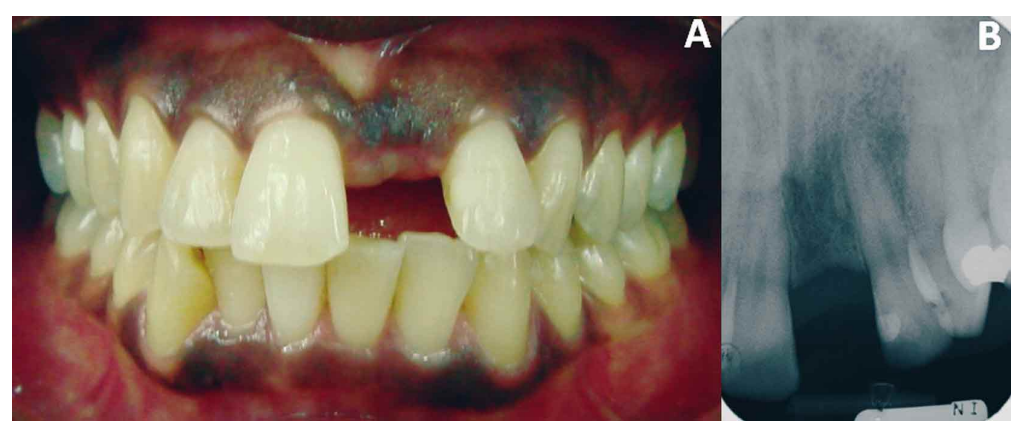

Fig. 2. A. Intraoral aspect, showing the absence of the tooth 21. This picture was taken 3 years after extraction have been performed. B. X-ray of the region of the tooth 21 absent (radiographic examination performed at the time of the expertise.

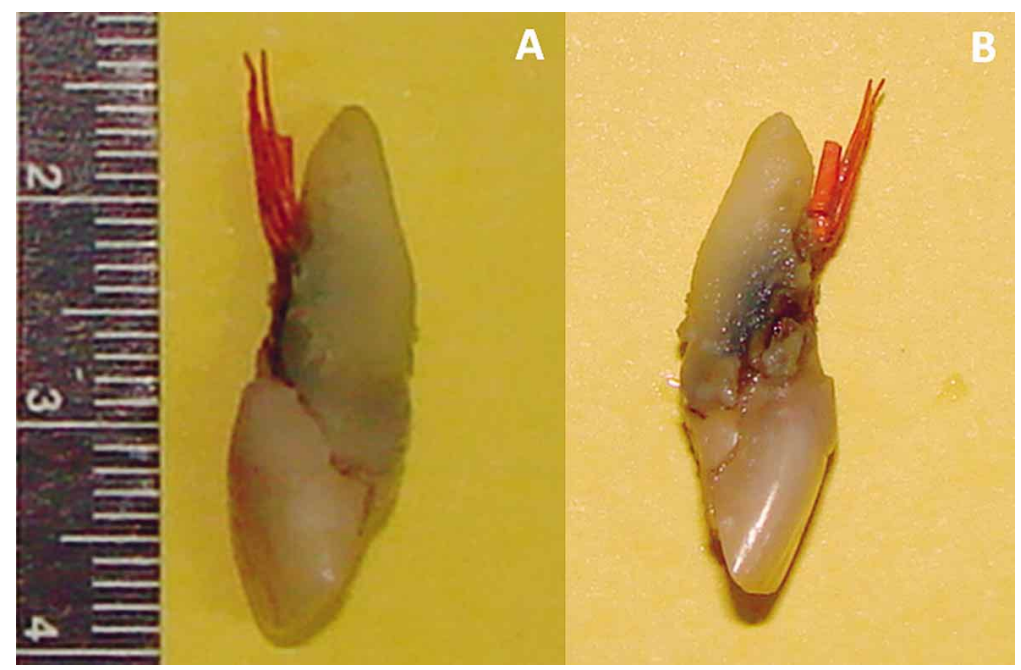

Fig. 3. A. Mesial view of tooth 21 extracted. B. Distal tooth of tooth 21 extracted. Note the large extravasation of the filling material in the middle third of the buccal surface. 


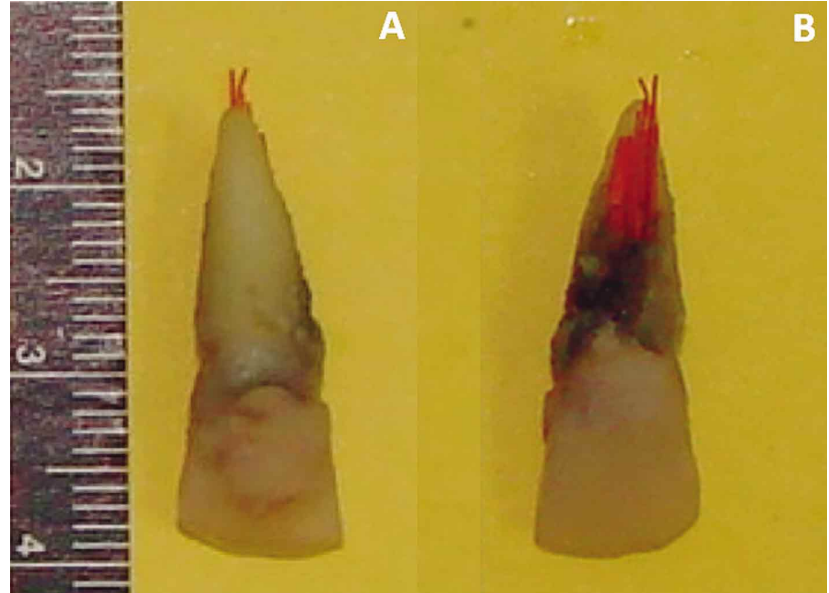

Fig. 4. A. Lingual view of tooth 21 extracted. B. Buccal view of tooth 21 extracted. Note the large extravasation of the filling material in the middle third of the buccal surface.

The patient was referred to an expert to perform the tooth extraction. The clinical examination showed a root perforation in the middle third of the buccal surface with large extravasation of filling material (Figs. 3 and 4). Thereafter, the patient filed a lawsuit against the former professional requiring compensation for moral and material damages.

The verdict was favorable to the patient, in which the trial judge granted the gain compensation for patient moral damages. Moreover, both dentists paid the dental treatment for oral rehabilitation of patient.

\section{DISCUSSION}

Previous studies reported that the perforations are the second leading cause of accidents in dental practice and represent about $9.6 \%$ of the cases of failures in endodontic treatment (Ford et al., 1995; Bruder et al., 1999).

The diagnosis of root perforation is mostly based in the symptoms and radiographic examinations. The classic symptoms are the sensitivity of the instrument introduction into to the root canal and bleeding. If the perforation is not diagnosed before the root canal filling, the patient will report an ongoing sensitivity to chewing, also under radiographic examination will be verified a diffuse radiolucent area adjacent to the drill site (Bruder et al.).

In the case here reported, since the second professional did not diagnose the drilling, the choice treatment was tooth extraction. However, treatment for root perforation can be performed by endodontic or surgical procedures (Cohen \& Schwartz, 1987). The treatments where recent lesions are intended to provide conditions for recovery and maintenance of healthy affected tissues, in order to stop the inflammatory process and prevent loss of periodontal support (Alhadainy \& Himel, 1994; Himel et al., 1985). Thus, if the treatment is performed immediately and with appropriated material and techniques, the drilling controlled by endodontic repair occurring in the injured region, if the conditions that are favorable to the perforation occurred with treatment (Balla et al., 1991; Silva et al., 2009).

Successful treatment of root perforation is observed when regeneration of the periapical tissue, absence of symptoms and radiolucent areas and radiological normality of the periodontal ligament are seen. Under histological examination, were observed: repair of the cement resorption dentin in bone turnover, periodontal fiber insertion in the newly formed hard tissue, restoration of the normal size of the periodontal space and absence of inflammation in periapical tissues (Balla et al.). Among the factors that can interfering in the prognosis are the level of the perforation occurred (below or above the bone), location, presence of contamination, size of perforation (the skill operator) and physical and chemical characteristics of the sealant (Alhadainy \& Himel; Himel et al.; Balla et al.).

As reported in this case, when the dentist did not present the patient with a treatment plan for the injury. The guilt of the professional can be identified through a clinical radiographic examination of the patient, in investigations of possible misdiagnosis, planning, and implementation of the treatment and detection of errors of prediction. In these cases the lack of patient care, the anticipated production of evidence has important relevance in the investigation of cases of malpractice against the dentist, as to the extent that the forensic examination is performed prior to initiation of legal proceedings, being established only the procedures that effectively performed (Silva et al.).

CONCLUSION. In endodontic practice, considering the particularities of each case, the verbal and/or written clarification of the risks to the patient is essential. Furthermore, here we show that the X-rays produced during dental treatment are essential in court proceedings, and must be properly processed and filed with the dental records serving as an important tool for the evaluation of the professional conduct. 
CAPUTO, I. G. C.; ROSSI, A. C.; FREIRE, A. R.; BASTOS, D. C.; SEVILLANO, M. G. C.; JÚNIOR, E. D. \& PRADO, F. B. Pérdida dentaria relacionada con una perforación radicular: Una visión legal en la práctica endodóntica. Int. J. Odontostomat., 8(2):221-224, 2014.

RESUMEN: La mayoría de las técnicas usadas en el tratamiento de endodoncia son limitadas hacia la cavidad dentinaria pulpar coronal y el canal radicular, evitándose alcanzar la región periapical alveolar. Sin embargo, algunos accidentes pueden ocurrir, tales como: fracturas de instrumentos de endodoncia, perforaciones radiculares, extravasación del material de obturación y fracturas dentarias entre otros. Cada uno involucra una respectiva complejidad. El objetivo de esta publicación fue reportar un caso donde ocurrió la pérdida de un diente permanente causado por una perforación radicular. En este caso la paciente presentó una demanda contra el profesional quién realizó el tratamiento de endodoncia, solicitando una compensación por daños morales y materiales. Se concluye que en la práctica de endodoncia, la especificación de los riesgos es crucial, considerándose las particularidades de cada caso. Así, se sugiere que una buena información verbal y escrita deberá ser proporcionada al paciente.

PALABRAS CLAVE: perforación radicular, accidentes, tratamiento de endodoncia, odontología legal.

\section{REFERENCES}

Alhadainy, H. A. \& Himel, V. T. An in vitro evaluation of plaster of Paris barriers used under amalgam and glass ionomer to repair furcation perforations. J. Endod., 20(9):449-52, 1994.

Arens, D. E. \& Torabinejad, M. Repair of furcal perforations with mineral trioxide aggregate: two case reports. Oral Surg. Oral Med. Oral Pathol. Oral Radiol. Endod., 82(1):848, 1996.

Balla, R.; LoMonaco, C. J.; Skribner, J. \& Lin, L. M. Histological study of furcation perforations treated with tricalcium phosphate, hydroxylapatite, amalgam, and Life. J. Endod., 17(5):234-8, 1991.

Bruder, G. A. 3rd; Mastromihalis, N.; Foroughi, K. \& Friedman, S. Perforation repairs. N. Y. State Dent. J., 65(5):26-7, 1999.

Cohen, S. \& Schwartz, S. Endodontic complications and the law. J. Endod., 13(4):191-7, 1987.

Ford, T. R.; Torabinejad, M.; McKendry, D. J.; Hong, C. U. \& Kariyawasam, S. P. Use of mineral trioxide aggregate for repair of furcal perforations. Oral Surg. Oral Med. Oral Pathol. Oral Radiol. Endod., 79(6):756-63, 1995.

Himel, V. T.; Brady, J. Jr. \& Weir, J. Jr. Evaluation of repair of mechanical perforations of the pulp chamber floor using biodegradable tricalcium phosphate or calcium hydroxide. J. Endod., 11(4):161-5, 1985.

Motamedi, M. H. Surgical management of iatrogenic root perforation following endodontic therapy. N. Y. State Dent. J., 72(5):40-1, 2006.

Silva, R. F.; Martins, E. C.; Prado, F. B.; Júnior, J. R. \& Júnior, E. D. Endoscopic removal of an endodontic file accidentally swallowed: clinical and legal approaches. Aust. Endod. J., 37(2):76-8, 2011.
Correspondence to:

Prof. Ana Cláudia Rossi

Department of Morphology, Anatomy area

Piracicaba Dental School

State University of Campinas - UNICAMP

Av. Limeira, 901, Postal Box \#52

13414-903,

Piracicaba, Sao Paulo

BRAZIL

Email: rossiac@fop.unicamp.br

Received: 25-02-2014

Accepted: 07-07-2014 